\title{
Utilization of Paper-Cone Water Cups as an Alternative Lignocellulose Waste Substrate in Pleurotus ostreatus Production
}

\author{
Suvit SUWANNO ${ }^{1, *}$, Aminoh AYAE ${ }^{1}$ and Nuttida SUWANNO ${ }^{2}$ \\ ${ }^{1}$ Faculty of Environmental Management, Prince of Songkla University, Songkhla 90112, Thailand \\ ${ }^{2}$ Faculty of Management Science, Prince of Songkla University, Songkhla 90112, Thailand
}

('Corresponding author's e-mail: suvit.su@psu.ac.th)

Received: 24 January 2017, Revised: 14 January 2019, Accepted: 5 February 2019

\begin{abstract}
This study examined the utilization of paper-cone water cups as an alternative substrate for oyster mushroom(Pleurotus ostreatus) production. The research was conducted by using bioconversion technology and a profitable method for converting lignocellulosic residue from municipal solid waste into protein-rich biomass, thereby reducing waste paper and enhancing environmental quality. The most suitable substrate for mycelial growth was waste paper from paper-cone water cups (WPC) combined with rubber wood sawdust (RWS) at a 75\%:25\% dry basis ratio. The substrate mixture was adjusted to a moisture content of $70 \%$, and the $\mathrm{C} / \mathrm{N}$ ratio was fixed at $20: 1$ by the addition of urea and supplementation with $8 \%$ rice bran. Spawn running used $10 \%$ seed inoculum. The mushrooms were cultivated on $500 \mathrm{~g}$ of substrate in polyvinyl chloride boxes $\left(405 \mathrm{~cm}^{3}\right)$ and incubated at $25^{\circ} \mathrm{C}$ in the dark with the relative humidity maintained at $70-80 \%$. The fastest spawn running (mycelia development) occurred at $5^{\text {th }}$ days, with pin head formation at $9^{\text {th }}$ days and fruiting body formation at $12^{\text {th }}$ days. The highest yield recorded was $26.59 \mathrm{~g} / 100 \mathrm{~g}$. Under these conditions, the potential lignocellulosic waste conversion (biological efficiency) was recorded as $88.64 \%$, and the protein content of $P$. ostreatus was $35.75 \%$ after 12 days of cultivation.
\end{abstract}

Keywords: Organic waste utilization, Lignocellulosic waste, Bioconversion, Pleurotus ostreatus, Environmental management

\section{Introduction}

The demand for packaging has increased due to social factors and technological changes such as population growth, the increased production of consumer goods and increased demands for human comfort. In particular, the packaging of food and drinking water, such as paper-cone water cups for drinking water, must be free of harmful contaminants. Such packaging is used at hospitals, food centers, shopping centers, fitness centers and libraries. The waste from these products is a major problem for every country. Garbage removal has become a major environmental issue in urban communities, and the amount of waste will increase with population expansion. In Thailand, it is reported that the volume of paper packaging is increasing every year. For example, in 2017, 185,000 tons of paper packaging was sold, an increase of $10 \%$ from 2016 [1].

Municipal solid waste (MSW) management in Thailand has long been considered one of the most severe environmental problems [2]. Daily MSW generation rates are $0.91 \mathrm{~kg}$ per capita in the smallest towns with populations lower than 5,000 and $1.89 \mathrm{~kg}$ per capita in fully urbanized towns with populations higher than 50,000, as classified by the Department of Local Administration, Thailand [3]. Over $60 \%$ of organic waste disposal in Thailand is by open dumping, as this method can effectively manage the high quantity of daily MSW at low cost [4]. However, in the long run, this approach incurs expensive operating costs and has significantly adverse environmental impact, contributing to climate change, since 
http://wjst.wu.ac.th

greenhouse gases including $\mathrm{CO}_{2}, \mathrm{CH}_{4}$ and $\mathrm{N}_{2} \mathrm{O}$ are emitted from both the anaerobic and aerobic decomposition of food, leaves and organic paper waste [5]. MSW is commonly known as trash and comprises everyday disposable items. Almost half of global MSW is organic matter, and $17 \%$ is paper [6].

Generally, paper waste is lignocellulosic material consisting of 40 to $50 \%$ cellulose, 25 to $30 \%$ hemicellulose and 15 to $20 \%$ lignin. Cellulose is commonly considered a polymer of glucose because cellobiose consists of 2 molecules of glucose. Hemicelluloses have sugar backbones composed of xylans, mannans and glucans, among which xylans and mannans are the most common products of the conversion or degradation of the polysaccharides in lignocellulose to form useful or high-value products [7-10]. Nevertheless, lignocellulosic materials are a good source of substrate for mushroom cultivation. White rot fungi or basidiomycetes can degrade all the major components of lignocellulosic material and are generally considered the main agents of natural lignin degradation [11,12].

Edible, medicinal, and wild mushrooms are the 3 major components of the global mushroom industry. The world production of cultivated, edible mushrooms has increased more than 30-fold since 1978 (from approximately 1 billion $\mathrm{kg}$ in 1978 to 34 billion $\mathrm{kg}$ in 2013). This increase is an extraordinary accomplishment, considering the world's population has increased only approximately 1.7 -fold during the same period. In 2015, edible mushroom production in Thailand reached a yield of $13.6 \mathrm{billion} \mathrm{kg}$ [13]. Asian countries (especially China, Japan, South Korea, Taiwan, Thailand, Vietnam, and India) are the main producers and consumers of oyster mushrooms (Pleurotus spp.), accounting for approximately $99 \%$ of the total volume $[13,14]$.

Oyster mushrooms are commercially important in the word mushroom market, and several species are grown commercially on a large and small scale in Thailand. Pleurotus species have been recognized as dual-function mushrooms with for humans, serving as both food and medicine. They are nutritive with good quantities of proteins, vitamins and minerals. Medicinally, they are been recommended for obese persons and diabetes patients because of their low caloric value and very low sugar and starch contents. Traditionally, extracts from Pleurotus species have been reported to be used in treating some ailments. Pleurotus spp. are preeminent wood decomposers; they grow on a wider array of forest and agricultural wastes than species of any other group $[15,16]$. They thrive on nearly all hardwoods, on wood byproducts (sawdust, paper waste, pulp sludge), on all cereal straws, on corn and corn cobs, on sugar cane bagasse, on coffee residues and on other materials too numerous to mention and difficult to imagine. In cultivating oyster mushrooms, several valuable byproducts are generated. Since lignocellulosic wastes are available in every corner of the world, they can be readily used in the cultivation of mushrooms and therefore could lead to a so-called white agricultural revolution in less developed countries and in the world at large. Mushrooms have a great impact on agriculture and the environment and great potential for socioeconomic impact in human welfare on local, national, and global levels $[17,18]$. The bioconversion of lignocellulosic residues through mushroom cultivation offers an opportunity to utilize renewable resources in the production of edible, protein-rich food that will sustain food security for the population. The cultivation of edible mushrooms is one of the most economically viable processes for the bioconversion of lignocellulosic wastes [12,19-22].

In Thailand, rubber wood sawdust (RWS) is the main substrate used for cultivating oyster mushrooms (P. ostreatus). Currently, biomass material such as RWS can be used generate electricity, heat or liquid fuel for motor vehicles that have substantially lower environmental impacts than traditional fossil fuels [23]. However, the cost of substrates for mushroom growth is an important part of the final cost of the mushroom biomass. The increasing cost of sawdust has become excessive for small-scale farmers, who are now searching for less expensive alternative substrates [17,20].

The main objective of this study was, therefore, to source alternative substrates from waste paper and assess the growth performance, yield and protein content of the resulting $P$. ostreatus. The utilization of waste paper for the production of cultured mushrooms can alleviate problems with MSW disposal and protect the environment while generating $P$. ostreatus as a nutritious food source. 


\section{Materials and methods}

\section{Organism acquisition}

A stock culture of $P$. ostreatus was obtained from the Environmental Biotechnology Research Unit, Department of Environmental Management, Prince of Songkla University. The culture was maintained on potato dextrose agar (PDA) slants at $4{ }^{\circ} \mathrm{C}$. Subculturing was performed every 30 days.

\section{Spawn preparation}

Oyster mushroom spawn was prepared with paddy grains (rice grain with husk). The grains were boiled until tender and then drained, and $50 \mathrm{~g}$ of spawning grains was packed in transparent polypropylene $(\mathrm{PP})$ bags $\left(12 \times 17 \mathrm{~cm}^{2}\right)$. The substrate bags were plugged with cotton, wrapped with clean paper and sterilized at $121{ }^{\circ} \mathrm{C}$ and $15 \mathrm{psi}$ for $20 \mathrm{~min}$. After sterilization and cooling, the substrate bags were inoculated with 5 fungal disks (diameter $6 \mathrm{~mm}$ ) from a 7-day-old pure culture and incubated in the dark at $25{ }^{\circ} \mathrm{C}$ for mycelial growth. After 12 - 15 days, the mycelium fully covered the grains [20].

\section{Substrate preparation}

Paper-cone water cups were obtained as lignocellulosic waste from Khunying Long Athakravisunthorn Learning Resources Center, Prince of Songkla University. The waste paper was chopped into $3-5 \mathrm{~cm}$ pieces and dried at $90{ }^{\circ} \mathrm{C}$ until reaching a constant weight. RWS was obtained from a wood processing plant in Yala Province and dried at $90^{\circ} \mathrm{C}$ until reaching a constant dry weight. Both substrates were stored in plastic bags at room temperature until use.

Fruiting body performance of $\boldsymbol{P}$. ostreatus under different growth conditions

Cultivation was performed in transparent PP bags $\left(12 \times 17 \mathrm{~cm}^{2}\right)$. To determine the optimal culture conditions and the optimal substrate, the following factors were studied. 1) Substrate ratio: The waste paper-cone water cups (WPC) and rubber wood sawdust (RWS) were mixed at various dry matter basis ratios of 100:0, 75:25, 50:50, 25:75 and 0:100, and the moisture content of the mixed substrates was adjusted to $70 \%$ with water. 2) Carbon/nitrogen $(\mathrm{C} / \mathrm{N})$ ratio: The $\mathrm{C} / \mathrm{N}$ ratio of the substrates was adjusted to 20 using urea as the nitrogen source. 3) Rice bran supplement: The medium was supplemented with 5 levels of rice bran: 0, 2, 4, 6, and $8 \%$. 4) Spawn inoculum: Three spawn levels (5, 10, and 15\%), defined as the spawn weight as a percentage of substrate weight on a dry weight basis, were tested. 5) Different containers were also used to evaluate the yield of $P$. ostreatus on the mixed paper waste substrates, namely, $15 \times 23 \mathrm{~cm}^{2}\left(345 \mathrm{~cm}^{2}\right)$ and polyvinyl chloride (PVC) boxes $9 \mathrm{~cm}$ long, $9 \mathrm{~cm}$ wide and $5 \mathrm{~cm}$ high $\left(405 \mathrm{~cm}^{3}\right)$. For the containers, $500 \mathrm{~g}$ of mixed substrate was used, while in the PP bags $\left(204 \mathrm{~cm}^{2}\right), 100 \mathrm{~g}$ of mixed substrate was used [19,24,25].

\section{Cultivation conditions for fruiting body production by $P$. ostreatus}

PP bags were filled with $95 \mathrm{~g}$ of substrate per bag. The tops of the bags were fitted with PVC necks, which served as the opening; they were plugged with cotton and covered with aluminum foil. Three replicates of each treatment were prepared in bags. The filled bags were then autoclaved at $121{ }^{\circ} \mathrm{C}$ and $15 \mathrm{psi}$ for $20 \mathrm{~min}$. After sterilization, the bags were left to cool and then inoculated aseptically with $5 \mathrm{~g}$ of spawn seed culture/bag. The inoculated bags were incubated at $25^{\circ} \mathrm{C}$ in the dark with the relative humidity maintained at $70-80 \%$ to allow full ramification of the mycelia. After complete colonization, the sides of the bags were cut without disturbing the bed and sprayed with water twice a day using a hand sprayer. Within 7-8 days of opening, pin heads and fruiting bodies appeared on all sides of the bag. During fruiting, $10-12 \mathrm{~h}$ of light was provided. The young mushrooms attained normal size after $2-3$ days, at which point the first crop was harvested from each bag [26]. The cultivation methodology and process conditions are presented in Figure 1. 


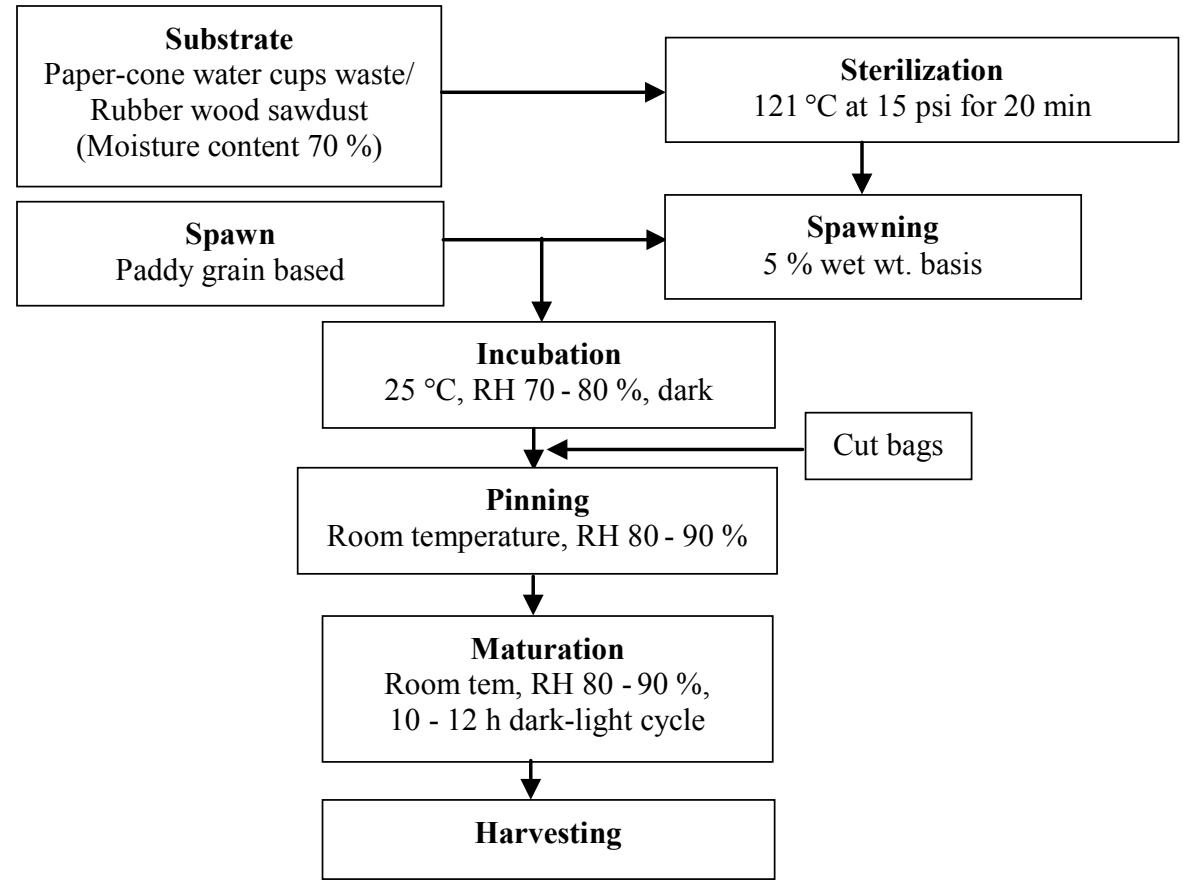

Figure 1 Flow diagram showing the cultivation method and process conditions for P. ostreatus on a mixed substrate of waste paper-cone water cups and RWS.

\section{Measurement of mycelial growth and chemical analysis}

Data concerning spawn running (mycelia growth) were recorded after complete colonization of the substrate, and pin head and fruit body formation were also noted. Mature fruiting bodies were harvested and weighed to calculate the yield and biological efficiency (BE) of P. ostreatus. Yield and BE are 2 expressions of productivity using Eqs. (1) and (2) [20,27]. Fresh oyster mushrooms were chopped and frozen at $-20^{\circ} \mathrm{C}$ for $48 \mathrm{~h}$ and then dried by lyophilization. The Kjeldahl method was used and the resulting total multiplied by a factor of 6.25 to ascertain the crude protein content of the mushrooms [28]. The total nitrogen and total organic carbon content of the substrates were analyzed by both photometric and Walkley-Black methods [29,30]. The C/N ratio was calculated by Eq. (3) [31].

Yield $(\mathrm{g} / \mathrm{g})=\quad$ Weight of fresh mushroom fruiting bodies $(\mathrm{g})$

Weight of the initial mass of substrate $(\mathrm{g})$

$\mathrm{BE}(\%)=$ Weight of fresh mushroom fruiting bodies $(\mathrm{g}) \times 100$

Weight of the initial dry mass of substrate $(\mathrm{g})$

$\mathrm{C} / \mathrm{N}$ ratio $=\frac{[(\% \text { Carbon } / 100) \times \text { dry weight }] \text { material } \mathrm{A}+\ldots}{[(\% \text { Nitrogen } / 100) \times \text { dry weight }] \text { material } \mathrm{A}+\ldots}$ 


\section{Statistical analysis}

Analysis of variance (ANOVA) was performed using the least significant difference (LSD) test at $p \leq 0.05$ to compare the mean values of average fresh weight and $\mathrm{BE}$.

\section{Results and discussion}

\section{Effect of substrate ratios}

The total organic carbon and total nitrogen dry matter contents were 17.28 and $0.24 \%$ for WPC and 36.84 and $1.81 \%$ for RWS, respectively, with $\mathrm{C} / \mathrm{N}$ ratios ranging from $72: 1$ to $20.35: 1$. The results indicated that the substrate mixture containing waste paper and RWS at a ratio of $50 \%: 50 \%$ and a $\mathrm{C} / \mathrm{N}$ ratio of 26.4 produced the highest yield and $\mathrm{BE}$ at $12.61 \mathrm{~g} / 100 \mathrm{~g}$ and $42 \%$, respectively. However, these values were not significantly different $(p \leq 0.05)$ from those obtained with the substrates RWS (control) with a $\mathrm{C} / \mathrm{N}$ ratio of 20.35:1 and WPC+RWS (25\%:75\%) with a $\mathrm{C} / \mathrm{N}$ ratio of 22.50:1. Spawn running, pin head formation and fruit body formation of the oyster mushrooms were recorded at 15, 21 and 25 days. However, the $\mathrm{C} / \mathrm{N}$ ratios of the substrates were very high, with WPC+RWS (75\%:25\%) at 35.19:1 and WPC (control) at 72:1, which resulted in lower yields and BE values (Table 1). The C/N substrate ratio is important for oyster mushroom cultivation because it affects the fermentation process, which requires available nitrogen for the growth of mycelia and the fruiting body [31-33]. Therefore, the $\mathrm{C} / \mathrm{N}$ ratio of the substrate material should be the first consideration for efficient mushroom production. This study investigated the possibility of WPC replacement by RWS and identified alternative and suitable substrates for oyster mushroom cultivation. Hence, for the next experiment, the substrate mixture of $75 \%: 25 \%$ WPC+RWS was selected. However, the total organic carbon content of waste paper is high because the material contains a wide range of cellulose and hemicellulose [24]. Consequently, the $\mathrm{C} / \mathrm{N}$ substrate ratio was prepared at $20: 1$ by the addition of urea as a nitrogen source. This ratio was also similar to the RWS control unit at 20.35:1. Moreover, Pleurotus spp. are reported to be efficient colonizers and degraders of lignocelluloses. The fungus accomplishes enzymatic degradation of the lignocellulosic portion of substrates by using enzymes such as endo-glucanase, $\beta$-glucosidase, xylase, laminarinase, laccase and polyphenol oxidase that are involved in the degradation of lignocellulose [34,35]. A positive relationship was achieved between the mushroom yield and cellulose contents revealed to be important factors in fruit body formation. Cellulose-rich organic materials have been reported to be good substrates for the cultivation of mushrooms [36].

Table 1 Effect of substrate ratio on the development phases, yield and BE of P. ostreatus.

\begin{tabular}{lcccccc}
\hline $\begin{array}{c}\text { Substrates } \\
\text { (\% ratio) }\end{array}$ & $\begin{array}{c}\text { C/N } \\
\text { Ratio }\end{array}$ & $\begin{array}{c}\text { Spawn } \\
\text { running } \\
\text { (days) }\end{array}$ & $\begin{array}{c}\text { Pin head } \\
\text { formation } \\
\text { (days) }\end{array}$ & $\begin{array}{c}\text { Fruit body } \\
\text { formation } \\
\text { (days) }\end{array}$ & $\begin{array}{c}\text { Yield } \\
\text { (g/100 g) }\end{array}$ & $\begin{array}{c}\text { Biological } \\
\text { efficiency } \\
\text { (\%) }\end{array}$ \\
\hline RWS (100) & 20.35 & 15 & 21 & 25 & $11.73 \pm 0.58^{\mathrm{a}}$ & $39.11 \pm 3.86^{\mathrm{a}}$ \\
$\begin{array}{l}\text { WPC+ RWS } \\
(25: 75)\end{array}$ & 22.50 & 15 & 21 & 25 & $11.70 \pm 0.22^{\mathrm{a}}$ & $39.00 \pm 1.49^{\mathrm{a}}$ \\
$\begin{array}{l}\text { WPC+ RWS } \\
(50: 50)\end{array}$ & 26.40 & 15 & 21 & 25 & $12.61 \pm 0.72^{\mathrm{a}}$ & $42.01 \pm 4.79^{\mathrm{a}}$ \\
$\begin{array}{l}\text { WPC+ RWS } \\
(75: 25)\end{array}$ & 35.19 & 17 & 24 & 29 & $5.79 \pm 0.55^{\mathrm{b}}$ & $19.31 \pm 3.67^{\mathrm{b}}$ \\
WPC $(100)$ & 72.00 & 18 & 26 & 31 & $1.95 \pm 0.40^{\mathrm{c}}$ & $6.49 \pm 2.67^{\mathrm{c}}$ \\
\hline
\end{tabular}

Note: Values within the same column followed by the same superscripts are significantly different $(p \leq 0.05)$; Values are means \pm SD from triplicate determination; RWS: Rubber wood sawdust; WPC: Waste paper-cone water cups. 
http://wjst.wu.ac.th

\section{Effect of added urea}

From the results in Table 2, the main substrate material alone often cannot provide sufficient nitrogen for optimal growth of oyster mushrooms; thus, urea was supplemented as a nitrogen source. The substrate mixture of WPC + RWS $(75: 25 \%)$ gave yield and BE values $(38.69 \%)$, that were not significantly different $(p \leq 0.05)$ from the control $(36.20 \%)$ when $10.4 \mathrm{mg} / \mathrm{kg}$ of urea was added as a nitrogen source to adjusted the $\mathrm{C} / \mathrm{N}$ ratio to 20:1. Mane et al. [9] reported that lignocellulosic materials are generally low in protein content and insufficient for the cultivation of mushrooms, which requires nitrogen phosphate and potassium. The $\mathrm{C}: \mathrm{N}$ ratio plays an important role in spawn running and the growth of fruiting bodies, and nitrogen supplementation is an important factor for the growth and yield of mushrooms. Junior et al. [37] suggested that a $\mathrm{C} / \mathrm{N}$ ratio between 15:1 and 30:1 favored primordial formation, a higher ratio favored mycelial growth, while a lower ratio favored fruiting body development. The results also revealed a significant positive correlation between $\mathrm{N} \%$ and the $\mathrm{C}: \mathrm{N}$ ratio, while $\mathrm{C} \%$ did not correlate with $\mathrm{N} \%$ or the $\mathrm{C}: \mathrm{N}$ ratio. Correlation coefficients between the substrate-derived variable $(\mathrm{C} \%, \mathrm{~N} \%$ or the $\mathrm{C}: \mathrm{N}$ ratio) and the growth parameters (total yield, BE, etc.) [38].

Table 2 Effect of urea on the development phases, yield and biological efficiency of P. Ostreatus cultivated on a mixed substrate of waste paper-cone water cups and rubber wood sawdust.

\begin{tabular}{llllllll}
\hline $\begin{array}{l}\text { Substrates } \\
(\% \text { ratio) }\end{array}$ & $\begin{array}{l}\text { Urea } \\
(\mathbf{m g} / \mathbf{k g})\end{array}$ & $\begin{array}{l}\text { C/N } \\
\text { ratio }\end{array}$ & $\begin{array}{l}\text { Spawn } \\
\text { running } \\
\text { (days) }\end{array}$ & $\begin{array}{l}\text { Pin head } \\
\text { formation } \\
\text { (days) }\end{array}$ & $\begin{array}{l}\text { Fruit body } \\
\text { formation } \\
\text { (days) }\end{array}$ & $\begin{array}{l}\text { Yield } \\
(\mathbf{g} / \mathbf{1 0 0} \mathbf{g})\end{array}$ & $\begin{array}{l}\text { Biological } \\
\text { efficiency } \\
(\%)\end{array}$ \\
\hline RWS (100) & - & 20.35 & 15 & 21 & 25 & $10.86 \pm 1.16^{\mathrm{a}}$ & $36.20 \pm 3.04^{\mathrm{a}}$ \\
$\begin{array}{l}\text { WPC+ RWS } \\
(75: 25)\end{array}$ & 10.40 & 20.00 & 17 & 24 & 28 & $11.61 \pm 0.80^{\mathrm{a}}$ & $38.69 \pm 2.68^{\mathrm{a}}$ \\
\hline
\end{tabular}

Note: WPC: Waste paper-cone water cups; RWS: Rubber wood sawdus,;Values are means \pm SD from triplicate determination within a column, mean values with different superscripts are significantly different $(p \leq 0.05)$.

\section{Effect of rice bran supplementation}

Different levels of rice bran supplementation (Table 3) significantly influenced the yield and BE of $P$. ostreatus. The highest yield at $24.83 \mathrm{~g} / 100 \mathrm{~g}$ and $\mathrm{BE}$ value of $82.78 \%$ were obtained with a substrate mixture of WPC+RWS (75\%:25\%) supplemented with $8 \%$ rice bran. These parameters showed a $109 \%$ increase in yield compared to the control with no rice bran added.This may be due to the rice bran supplement additive, which increased yield by providing specific nutrients such as carbohydrates, amino acids and mineral elements to promote the growth of mycelium [39]. However, mixtures that contain bran (25\%) increase the risk of contamination because supplements also provide good nutrients to other microorganisms [24]. Tesfaw et al. [40] stated that supplements alter the physical conditions of the substrate, making it more suitable for mushroom cultivation. Naraian et al. [10,41] reported on the occurrence and nature of loss in mushroom yield due to bacterial disease in Pleurotus species bacterial diseases of P.ostreatus have affected many mushroom farms, and the pathogen is known to cause, at least, the deformation of the fruit bodies. The exact reasons for the occurrence of the disease are not known, except, possibly, the use of contaminated equipment or the adoption of a poor pasteurization technique [7]. Problems with mycelial growth in the present study are not associated with pasteurization because contamination was observed after mycelial growth had been completed. The addition of $8 \%$ rice bran as a supplement to the waste paper reduced the cultivation time for spawn running, pin head formation and fruit body formation by 1 day.

\section{Effect of spawn inoculum}

Spawn inoculation level is an important factor that affects the production costs of mushroom cultivation. Using the lowest inoculation level possible without sacrificing mushroom yield gives the best economics [27]. Among the 3 tested spawn levels (5, 10 and 15\%), the $10 \%$ spawn level resulted in a 
http://wjst.wu.ac.th

significantly higher mushroom yield $(25.71 \mathrm{~g} / 100 \mathrm{~g})$ and BE (85.69 \%) (Table 4). The optimal conditions for $P$. ostreatus cultivation were WPS+RWS (75\%:25\%) supplemented with urea at $10.40 \mathrm{mg} / \mathrm{kg}(\mathrm{C} / \mathrm{N}$ ratio: 20 ) and $8 \%$ rice bran dry weight with $10 \%$ spawn inoculum. Incubation time was reduced to one week instead of 3 to 4 weeks. Mansour-Benamar et al. [42] suggested that a higher rate of spawn inoculation $(>10 \%)$ enhanced mycelial growth and reduced the incubation period, but the increased expense was not economically attractive. In addition, using large amounts of spawn-risked overheating in the incubator and excess heat emitted by the fungal activity may kill the mycelium. The inoculation rate of $10 \%$ used for the production of oyster mycelium on the mixed substrate of WPC+RWS (75\%:25\%) was also chosen to allow rapid development of fungus and prevent mold contamination [42]. Bhatti et al. [43] studied the growth and yield of $P$. ostreatus on wheat straw affected by different spawn rates ( $1 \%$ to $10 \%$ ). They concluded that spawning at a rate of $7 \%$ is the best dose for obtaining early and high yielding $(\mathrm{BE}=45.4 \%)$ with a maximum number of flushes and fruiting bodies per bag.

Table 3 Effect of rice bran on the development phases, yield and biological efficiency of P. Ostreatus cultivated on a mixed substrate of waste paper-cone water cups and rubber wood sawdust.

\begin{tabular}{lcccccc}
\hline $\begin{array}{l}\text { Substrates } \\
(\% \text { ratio) }\end{array}$ & $\begin{array}{c}\text { Rice bran } \\
(\%)\end{array}$ & $\begin{array}{c}\text { Spawn } \\
\text { running } \\
\text { (days) }\end{array}$ & $\begin{array}{c}\text { Pin head } \\
\text { formation } \\
\text { (days) }\end{array}$ & $\begin{array}{c}\text { Fruit body } \\
\text { formation } \\
\text { (days) }\end{array}$ & $\begin{array}{c}\text { Yield } \\
(\mathbf{g} / \mathbf{1 0 0} \mathbf{g})\end{array}$ & $\begin{array}{c}\text { Biological } \\
\text { efficiency } \\
(\%)\end{array}$ \\
\hline $\begin{array}{c}\text { WPC+RWS } \\
(75: 25)\end{array}$ & 0 & 17 & 24 & 28 & $11.89 \pm 1.02^{\mathrm{e}}$ & $39.61 \pm 3.39^{\mathrm{e}}$ \\
$\begin{array}{c}\text { WPC+RWS } \\
(75: 25)\end{array}$ & 2 & 17 & 24 & 28 & $17.11 \pm 0.97^{\mathrm{d}}$ & $57.02 \pm 3.23^{\mathrm{d}}$ \\
$\begin{array}{c}\text { WPC+RWS } \\
(75: 25)\end{array}$ & 4 & 16 & 23 & 27 & $21.51 \pm 1.08^{\mathrm{bc}}$ & $71.71 \pm 3.61^{\mathrm{bc}}$ \\
$\begin{array}{c}\text { WPC+RWS } \\
(75: 25)\end{array}$ & 6 & 16 & 23 & 27 & $22.12 \pm 0.89^{\mathrm{b}}$ & $73.73 \pm 2.96^{\mathrm{b}}$ \\
$\begin{array}{c}\text { WPC+RWS } \\
(75: 25)\end{array}$ & 8 & 16 & 23 & 27 & $24.83 \pm 0.41^{\mathrm{a}}$ & $82.78 \pm 1.38^{\mathrm{a}}$ \\
\hline
\end{tabular}

Note: WPC: Waste paper-cone water cups; RWS: Rubber wood sawdust; Values are means \pm SD from triplicate determination within a column, mean values with different superscripts are significantly different $(p \leq 0.05)$

Table 4 Effect of spawn inoculum on the development phases, yield and biological efficiency of $P$. ostreatus cultivated on a mixed substrate of waste paper-cone water cups and rubber wood sawdust.

\begin{tabular}{ccccccc}
\hline $\begin{array}{c}\text { Substrates } \\
\text { (\% ratio) }\end{array}$ & $\begin{array}{c}\text { Spawn } \\
(\mathbf{\%})\end{array}$ & $\begin{array}{c}\text { Spawn } \\
\text { running } \\
\text { (days) }\end{array}$ & $\begin{array}{c}\text { Pin head } \\
\text { formation } \\
\text { (days) }\end{array}$ & $\begin{array}{c}\text { Fruit body } \\
\text { formation } \\
\text { (days) }\end{array}$ & $\begin{array}{c}\text { Yield } \\
(\mathbf{g} / \mathbf{1 0 0} \mathbf{g})\end{array}$ & $\begin{array}{c}\text { Biological } \\
\text { efficiency } \\
\text { (\%) }\end{array}$ \\
\hline $\begin{array}{c}\text { WPC+ RWS } \\
(75: 25)\end{array}$ & 5 & 15 & 22 & 26 & $21.72 \pm 0.43^{\mathrm{c}}$ & $72.39 \pm 1.45^{\mathrm{c}}$ \\
$\begin{array}{c}\text { WPC+ RWS } \\
(75: 25)\end{array}$ & 10 & 6 & 12 & 16 & $25.71 \pm 0.60^{\mathrm{a}}$ & $85.69 \pm 2.00^{\mathrm{a}}$ \\
$\begin{array}{c}\text { WPC+ RWS } \\
(75: 25)\end{array}$ & 15 & 5 & 10 & 14 & $24.53 \pm 2.26^{\mathrm{b}}$ & $82.79 \pm 1.50^{\mathrm{b}}$ \\
\hline
\end{tabular}

Note: WPC: Waste paper-cone water cups; RWS: Rubber wood sawdust; Values are means \pm SD from triplicate determination within a column, mean values with different superscripts are significantly different $(p \leq 0.05)$ 
http://wjst.wu.ac.th

\section{Effect of container system}

The effect of using different types of container (PP bags and PVC boxes) on the growth phase and yield of $P$. ostreatus is presented in Table 5. Oyster mushrooms were chosen for study on the basis of their fast growth rate, short incubation time and BE with a substrate mixture of WPC+RWS (75\%:25\%). The results indicated that the spawn running, pin head and fruit body formation required a shorter incubation period when cultivated in PVC boxes. Furthermore, the substrate mixture in the PVC boxes attained higher BE $(88.64 \%)$ and yield $(26.59 \mathrm{~g} / 100 \mathrm{~g})$ than the PP bags because mushrooms emit heat during incubation, and the PP bags overheated more easily than the larger PVC boxes, which offered greater surface area allowing increased airflow. Commercial growers prefer PVC boxes to PP bags for pileus mushroom cultivation; and allowed, both container types produced mushrooms of good size and shape (Figure 2).

Table 5 Effect of container type on the development phases, yield and biological efficiency of $P$. ostreatus cultivated on mixed substrate of waste paper-cone water cups and rubber wood sawdust.

\begin{tabular}{ccccccc}
\hline $\begin{array}{c}\text { Substrates } \\
(\% \text { ratio) }\end{array}$ & Container & $\begin{array}{c}\text { Spawn } \\
\text { running } \\
\text { (days) }\end{array}$ & $\begin{array}{c}\text { Pin head } \\
\text { formation } \\
\text { (days) }\end{array}$ & $\begin{array}{c}\text { Fruit body } \\
\text { formation } \\
\text { (days) }\end{array}$ & $\begin{array}{c}\text { Yield } \\
(\mathbf{g} / \mathbf{1 0 0} \text { g) }\end{array}$ & $\begin{array}{c}\text { Biological } \\
\text { efficiency } \\
(\mathbf{\%})\end{array}$ \\
\hline $\begin{array}{c}\text { WPC+ RWS } \\
(75: 25)\end{array}$ & PP bags & 6 & 12 & 16 & $24.86 \pm 1.83^{\mathrm{b}}$ & $82.69 \pm 6.13^{\mathrm{b}}$ \\
$\begin{array}{c}\text { WPC+ RWS } \\
(75: 25)\end{array}$ & PVC boxes & 5 & 9 & 12 & $26.59 \pm 1.38^{\mathrm{a}}$ & $88.64 \pm 4.61^{\mathrm{a}}$ \\
\hline
\end{tabular}

Note: WPC: Waste paper-cone water cups; RWS: Rubber wood sawdust; PP: polypropylene; PVC: polyvinyl chloride.
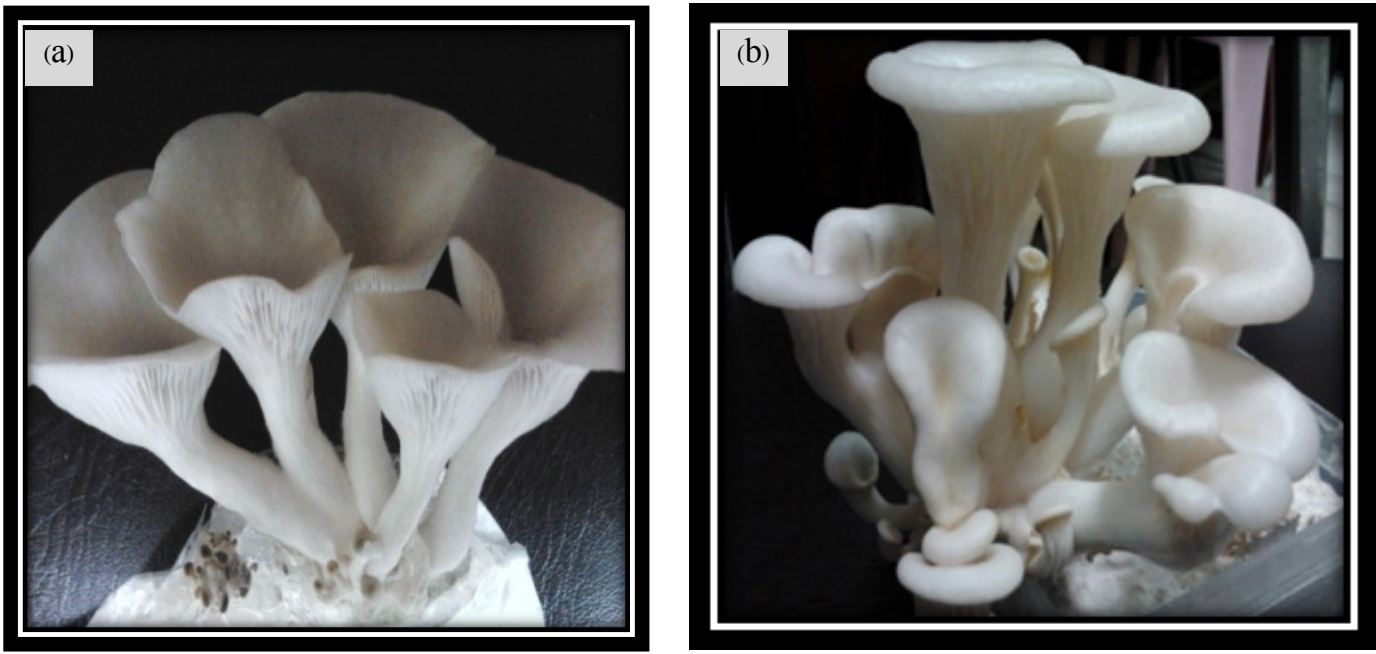

Figure 2 Morphology of $P$. ostreatus cultivated on alternative substrates of waste paper-cone water cups as lignocellulosic waste and rubber wood sawdust at a ratio of 75:25 (\% w/w) in PP bags (a) and PVC boxes (b). 
http://wjst.wu.ac.th

\section{Protein content}

The protein content of $P$. ostreatus was $35.75 \%$ at $12^{\text {th }}$ days of cultivation on the optimal substrate mixture WPC+RWS (75:25) in PVC containers. This protein content was higher than previously reported figures. Mandeel et al. [20] reported that the protein content of $P$. ostreatus varied from 21.3 to $27.8 \%$, while the results by Sharma et al. [44] ranged between 22.8 and $25.97 \%$. The richness of the substrates in usable nitrogen after spawn run may be a factor in enhancing the yield and quality of oyster mushrooms, in addition to the bioconversion and bioaccumulation efficiency. In this study, the addition of fresh supplementation of rice bran and urea as a nitrogen source could, in part, account for protein content [20]. Mane et al. [8] also reported that several nitrogen sources used as supplements to rice straw, yeast mud, cotton seed powder and rice bran proved ideal in increasing the mushroom yield and protein content.

\section{Conclusions}

Rubber wood sawdust is the most popular basal ingredient for the cultivation of oyster mushrooms in Thailand. However, the cost of sawdust is high, and less expensive alternative substrates are required to reduce the cost of cultivation.Waste paper-cone water cups, as a lignocellulosic waste, can be considered practical and economically feasible for the cultivation of $P$. ostreatus because of their ready availability. The paper waste can be combined with other agricultural wastes to produce an economical substrate. Here, the substrate was mixed with $75 \%$ waste paper-cone water cups and $25 \%$ rubber wood sawdust (70\% moisture content) supplemented with $8 \%$ rice bran, and urea was added at $10.4 \mathrm{mg} / \mathrm{kg}$ to adjust the $\mathrm{C} / \mathrm{N}$ ratio to 20:1. Five hundred grams of substrate mixture was placed in PVC boxes $\left(405 \mathrm{~cm}^{3}\right)$ with $10 \%$ spawn inoculation. The results indicated that these parameters significantly increased the yield, $\mathrm{BE}$ and protein content for oyster mushroom cultivation and reduced production time. This material mixture could be used as an inexpensive alternative substrate for $P$. ostreatus cultivation.

\section{Acknowledgements}

National Research council of Thailand and Graduate School, Prince of Songkla University, Thailand supported this research financially.

\section{References}

[1] Packaging Intelligence Unit.Thailand Packaging Industry Market Reports.Available at: http://packaging.oie.go.th/new/search_manufacturing_data.php?ACTION=SEARCH, accessed May 2018.

[2] A Sharp and J Sang-Arun. A Guide for Sustainable Urban Organic Waste Management in Thailand: Combining Food, Energy, and Climate Co-benefits. IGES Policy report. Asia-Pacific Network for Global Change Research (APN) Thailand, 2012, p. 17-43.

[3] A Challcharoenwattana and C Pharino. Co-benefits of household waste recycling for local community's sustainable waste management in Thailand. Sustainability 2015; 7, 7417-37.

[4] C Chiemchairi, JP Juanga and C Visvanathan. Municipal solid waste management in Thailand and disposal emission inventory. Environ. Monit. Assess. 2007; 135, 13-20.

[5] M Badu, SK Twumasi and NO Boadi. Effect of lignocellulosic in wood used as substrate on the quality yield of mushroom. Food Nutr. Sci. 2011; 2, 780-4.

[6] T Chinda, N Leewattana and N Leeamnuayjaroen. The study of Landill sitable in Thailand. In: Proceedings of the $1^{\text {st }}$ Mae Fah Lunng University International Conference, Chiang Rai, Thailand, 2012, p.1-8.

[7] S Yildiz, ÜC Yildiz, ED Gezer and A Temiz. Some lignocellulosic wastes uses as raw material in cultivation of the Pleurotus ostreatus culture mushroom. Process. Biochem. 2002; 38, 301-6.

[8] VP Mane, SS Patil, AA Syed and MMV Baig. Bioconversion of low quality lignocellulosic agricultural waste into edible protein by Pleurotus sajor-caju (Fr.) Singer. J. Zhejiang Univ. Sci. B $2007 ; \mathbf{8}, 745-51$. 
http://wjst.wu.ac.th

[9] EA Adebayo and D Martinez-Carrera. Oyster mushrooms (Pleuurotus) are useful for utilizing lignocellulosic biomass. Afr. J. Biotech. 2015; 14, 52-67.

[10] R Naraian, MP Singh and S Ram. Supplementation of basal substrate to boost up substrate strength and Oyster mushroom yield: An overview of substrates and supplements. Int. J. Curr. Microbiol. Appl. Sci. 2016; 5, 543-53.

[11] R Zhang, X Li and JG Fadel. Oyster mushroom cultivation with rice and wheat straw. Bioresour. Tech. 2012; 82, 277-84.

[12] M Dashtban, H Schrft and W Qin. Fungal bioconversion of lignocellulosic residues: Opportunities \& perspectives. Int. J. Biol. Sci. 2009; 5, 578-95.

[13] DJ Royse, J Baarsand and Q Tan. Current Overview of Mushroom Production in the World. In: DC Zied and A Pardo-Gimenez (eds.). Edible and Medicinal Mushrooms: Technology and Applications. Wiley, New York, 2017, p. 5-12.

[14] LJLD Van-Griensven. Mushrooms as a Conventional Food Mushrooms: Conventional Food and Alternative Medicine. In: I Milenkovic and I MIlosavljevic (eds.). Mushroom Cultivation Manual for the Small Mushroom Entrepreneur. Eko-offungi, Belgrade, Serbia, 2017, p. 7-16.

[15] JK Oloke and EA Adebayo. Effectveness of immunotherapies from oyster mushroom (Pleurotus species) in the management of immunocompromised patients. Int. J. Immunol. 2015; 3, 8-20.

[16] A Gregori, M Svagelj and J Pohleve. Cultivation techniques and medicinal properties of Pleurotus spp. Food Tech. Biotech. 2007; 45, 238-49.

[17] RP Tengerdy and G Szakacs. Bioconversion of lignocellulose in solid substrate fermentation. Biochem. Eng. J. 2003; 13, 169-79.

[18] ST Chang and SP Wasser. The Cultivation and Environmental Impact of Mushrooms. Oxford Research encyclopedia of environmental science. Oxford University Press, Oxford, 2017.

[19] AN Philippoussis, G Zervakis and P Diamantopoulou. Bioconversion of agricultural lignocllulosic waste through the cultivation of the edible mushrooms Agrocybe aegerita, Volvariella volvacea and Pleurotus spp. World J. Microbiol. Biotech. 2001; 17, 191-200.

[20] Q Mandeel, AAA Al-Laith and SA Mohamed. Cultivation on oyster mushroom (Pleurotus spp.) on various lignocellulosic wastes. World J. Microbiol. Biotech. 2005; 21, 601-7.

[21] G Koutrotsios, KC Mountzouris, I Chatzipavlidis and GI Zervakis. Bioconversion of lignocellulosic residues by Agrocybe cylindracea and Pleurotus ostreatus mushroom fungi: Assessment of their effect on the final product and spent substrate properties. Food Chem. 2014; 61, 127-35.

[22] R Sindnu, P Binod and A Pandey. Biological pretreatment of lignocellulosic biomass: An overview. Bioresour. Tech. 2016; 199, 76-82.

[23] S Papong, C Yuvaniyama, P Lohsomboon and P Malakul. Overview of biomass utilization in Thailand. In: Proceedings of the Meeting for LCA in ASEAN Biomass Project, International Conference Center Bangkok, 2004.

[24] S Yildiz, ÜC Yildiz, ED Gezer and A Temiz. Some lignocellulosic wastes uses as raw material in cultivation of the Pleurotus ostreatus culture mushroom. Process. Biochem. 202; 38, 301-6.

[25] R Zhang, X Li and JG Fadel. Oyster mushroom cultivation with rice and wheat straw. Bioresour. Tech. 2002; 82, 277-84.

[26] E Harada, T Morizono, T Sumiya and S Meguro. Production of andean-patagonic edible mushroom Grifola gargal on wood-based substrates. Mycoscience 2015; 56, 616-21.

[27] E Baysal, H Peker, MM Yalinkili cand A Temiz. Cultivation of oyster mushroom on waste paper with some added supplementary materials. Bioresour. Tech. 2003; 89, 95-7.

[28] Association of Official Analytical Chemists (AOAC). Official Methods of Analysis of the Association of Official Analytical Chemists. $19^{\text {th }}$ ed. AOAC lnc. Washington DC, USA, 2012.

[29] R Novozamsky, JV Eck, CH Shcouwenburg and VI Wallinga. Total nitrogen determination in plant material by means of the indophenol blue method. J. Agri. Sci. 1974; 22, 3-5.

[30] A Walkley and IA Black. An examination of degtiareff method for determining soil organic matter and apropos modification of the chromic acid titration method. Soil Sci. 1934; 37, 29-38.

[31] G Tchobanoglous, H Thesisen and S Vigil. Integrated Solid Waste Management Engineering Principles and Management Issues. McGraw-Hill, Singapore, 1993. 
[32] KW Choi. Shelf Cultivation of Oster Mushroom. Mushroom Growers Handbook 1 Oyster Cultivation. Mush World, 2004, p. 153-65.

[33] PA Philippoussis, PA Diamantopoulou and GI Zervakis. Correlation of the properties of several lignocellulosic substrates to the crop performance of the shiitake mushroom Lentinula edodes. World J. Microbiol. Biotech. 2003; 19, 551-7.

[34] D Salmones, M Gerardo, LM Raos and KN Waliszewski. Cultivation of Shitatake mushroom, Lentimula edodes in several lignocellulosic materials originating from the tropics. Agronomie 1999; 19, 13-9.

[35] M Obodia, J Cleland-Okine and KA Vowotor. Comparative study on the growth and yield of Pleurotus ostreatus mushroom on different lignocellulosic by-products. J. Ind. Microbiol. Biot. 2003; 30, 146-9.

[36] EA Adebayo and D Martiinez-Carrera. Oster mushroom (Pleurotus) are useful for utilizing lignocellulosic biomass. Afr. J. Biotech. 2015; 14, 52-67.

[37] Z Junior, L Luiz, GA Linde and NB Colauto. Carbon-to-nitrogen ratios for Agaricus brasiliensis on the axenic method. Acta Sci. Agron. 2010; 32, 55-60.

[38] S Rezaean and H Pourianfar. A comparative study on bioconversion of different agro wastes by wild and cultivated strains of Flammulina velutipes. Waste Biomass Valori. 2016; 8, 2631-42.

[39] M Moonmoon, MN Uddin, S Ahmed, NJ Shelly and Md A Khan. Cultivation of different strains of king oyster mushroom (Pleurotus eryngii) on sawdust and rice straw in Bangladesh. Saudi J. Biol. Sci. 2010; 17, 341-5.

[40] A Tesfaw, A Tadesse and G Kiros. Optimization of oyster (Pleurotus ostreatus) mushroom cultivation using locally available substrates and materials in Debre Berhan, Ethiopia. Appl. Microbiol. Biotech. 2015; 3, 15-20.

[41] R Naraian, RK Sahu, S Kumar, SK Garg, CS Singh and RS Kanaujia. Influence of different nitrogen rich supplements during cultivation of Pleurotus florida on corncob substrate. Environmentalist 2009; 29, 1-7.

[42] M Mansour-Benamar, JM Savoie and L Chavant. Valorization of solid olive mill wastes by cultivation of a local strain of edible mushrooms. Comptes Rendus Biol. 2013; 336, 407-15.

[43] MI Bhatti, MM Jiskani, KH Wagan, MA Pathan and MR Magsi. Growth, development and yield of oyster mushroom, Pleuotus ostreatus (JACQ. EX. FR.) Kummer as affected by different spawn rates. Pak. J. Bot. 2007; 39, 2685-92.

[44] S Sharma, RPK Yadav and CP Pokhrel. Growth and yield of oyster mushroom (Pleurotus ostreatus) on different substrates. J. New Biol. Rep. 2013; 2, 3-8. 